\title{
Fertilizer Recommendation for Potato-Boro-T.Aman Cropping Pattern in Old Himalayan Piedmont Plain Soils of North-West Bangladesh
}

\author{
M. M. Ali, N. Sobhan*, R. R. Sarker and M. H. Rahman
}

Soil Science Division, Bangladesh Institute of Nuclear Agriculture, Mymensingh

\begin{abstract}
Field experiments were carried out with Potato-Boro-T. aman cropping pattern at Birgonj, Dinajpur and Debigonj, Panchagarh during the consecutive years of 2011-12 to 2012-13 in the Old Himalayan Piedmont Plain Soils under agroecological zone (AEZ) 1 of North-West Bangladesh. The experiments were designed with eight treatments and laid out in randomized complete block design (RCBD) with three replications. The treatment combinations were: $\mathrm{T}_{1}(100 \% \mathrm{STB}), \mathrm{T}_{2}\left(\mathrm{~T}_{1}+25 \% \mathrm{~N}\right), \mathrm{T}_{3}\left(\mathrm{~T}_{1}+25 \%\right.$ $\mathrm{NP}), \mathrm{T}_{4}\left(\mathrm{~T}_{1}+25 \% \mathrm{NK}\right), \mathrm{T}_{5}\left(\mathrm{~T}_{1}+25 \% \mathrm{PK}\right), \mathrm{T}_{6}\left(\mathrm{~T}_{1}+25 \% \mathrm{NPK}\right), \mathrm{T}_{7}\left(75 \%\right.$ of $\left.\mathrm{T}_{1}\right)$ and $\mathrm{T}_{8}$ (Control). Results indicated that application of different fertilizers significantly affected the grain yield at all of the locations. The highest yield was found in treatment $\mathrm{T}_{6}\left(\mathrm{~T}_{1}+25 \% \mathrm{NPK}\right)$. Statistically identical yield was observed in treatments $\mathrm{T}_{3}, \mathrm{~T}_{4}$ and $\mathrm{T}_{5}$ at Birgonj, Dinajpur and $\mathrm{T}_{3}$ at Debigonj, Panchagar. All the treatment combinations gave significantly higher grain yield over the control at both of the locations. The highest straw yield was found in treatment $\mathrm{T}_{6}\left(\mathrm{~T}_{1}+25 \% \mathrm{NPK}\right)$. Statistically identical straw yield was found in $\mathrm{T}_{3}$ and $\mathrm{T}_{4}$ at Birgonj, Dinajpur and $\mathrm{T}_{1}, \mathrm{~T}_{4}$ and $\mathrm{T}_{5}$ at Debigonj, Panchagarh. Significantly the lowest yield was obtained in control treatment $\left(\mathrm{T}_{8}\right)$ in both of the locations. The highest total $\mathrm{N}$ uptake was observed in treatment $\mathrm{T}_{6}$ and a similar trend of total $\mathrm{N}$ uptake was observed for $\mathrm{P}$ uptake in both the locations. Treatment $\mathrm{T}_{6}$ showed the highest uptake of total $\mathrm{K}$. The highest uptake of total $\mathrm{S}$ was observed in treatment $\mathrm{T}_{6}$ at Birgonj, Dinajpur and $\mathrm{T}_{3}$ at Debigonj, Panchagarh. However, the lowest total N, P, K and S uptake was observed in control treatment $\left(\mathrm{T}_{8}\right)$ at both of the locations. The partial economic analysis showed the highest MBCR of 4.57 in $\mathrm{T}_{3}$ at Birgonj, Dinajpur and 4.75 in $\mathrm{T}_{6}$ treatments at Debigonj, Panchagarh respectively. Fertilizer doses recommended for Potato-Boro-T.aman pattern were $\mathrm{N}_{169} \mathrm{P}_{31} \mathrm{~K}_{135} \mathrm{~S}_{12} \mathrm{Zn}_{2} \mathrm{~B}_{1}-\mathrm{N}_{175} \mathrm{P}_{10} \mathrm{~K}_{75} \mathrm{~S}_{10} \mathrm{Zn}_{1} \mathrm{~B}_{0.5}$ $\mathrm{N}_{80} \mathrm{P}_{7.5} \mathrm{~K}_{32} \mathrm{~S}_{8}$ at Birgonj, Dinajpur and $\mathrm{N}_{188} \mathrm{P}_{23} \mathrm{~K}_{169} \mathrm{~S}_{8} \mathrm{Zn}_{2} \mathrm{~B}_{1}-\mathrm{N}_{188} \mathrm{P}_{10} \mathrm{~K}_{94} \mathrm{~S}_{8} \mathrm{Zn}_{1} \mathrm{~B}_{0.5}-\mathrm{N}_{84} \mathrm{P}_{7.5} \mathrm{~K}_{40} \mathrm{~S}_{6}$ at Debigonj, Panchagarh.
\end{abstract}

Key words: Fertilizer, Potato-Boro-T. aman pattern, Nutrient balance

\section{Introduction}

Over few decades, population has excreted enormous pressure on the land resource base in Bangladesh for deriving necessary food, fibre and fuel. Crop intensification in agricultural land has increased remarkably along with increased irrigation replacing the traditional systems. Ali et al. (1997a-b) reported that the soils in Bangladesh are depleted with many of the essential nutrients, particularly because of intensive cropping along with HYV of crops having almost no return from organic recycling. It inflicted serious injury to the land qualities due to nonjudicious extraction of plant nutrients by growing crops without proper replenishment (Saheed, 1991). As a consequence of irrational land use, depletion of soil organic matter and deficiency/imbalance in plant nutrient status emerged as major problems. The amount of nutrient taken up by a crop is closely related to the total amount of biomass it produces. In general, higher the yield level higher is the amount of nutrient removed by the crop (Bhuiyan, 1993).

Present decline or stagnation of major crop yield is the cumulative effects of low organic matter content, nutrient depletion, imbalanced fertilization and poor management practices of agriculture in Bangladesh (Mia, 1994). Karim (1995) emphasized that everybody should be aware of the phenomenon of nutrient depletion/mining from the soils. Nutrient mining is one of the major causes for stagnation or decline in yield of major crops of Bangladesh. If this problem of nutrient depletion is not corrected it will cause a serious damage of the soil and to the welfare of mankind.

Relatively higher amount of fertilizers need to be used in HYV of different crop cultivation. Fageria et al. (1991) stated that supplying of mineral nutrients to crops in adequate amounts is one of the most important factors in achieving higher productivity. Fertilizer has now become a very costly commodity of agriculture in Bangladesh. A huge amount of foreign currency is needed to import different fertilizers in the country. It is, therefore, urgently needed to develop fertilizer management packages in such a way that it suited farmers' resource constraints for ensuring the high use efficiency of fertilizers. Abedin and Mukhopadhya (1990) reported that cropping system approach is essential for tapping up the residual effect of fertilizer nutrients to rationalize their use. Information based on soils, crops and cropping pattern, BARC prepared 
Fertilizer Recommendation Guide - 2012 to adopt balanced fertilization for sustaining crop production in the country (FRG, 2012). This national Fertilizer Recommendation Guide need to be further updated and verified for different dominant cropping patterns at different AEZs. Therefore, we attempted to develop fertilizer recommendation for Potato-Boro-T. aman pattern in the Old Himalayan Piedmont Plain Soils under AEZ 1.

\section{Materials and Methods}

\section{Description of the experimental sites}

Field experiments were carried out with PotatoBoro-T. aman pattern at Birgonj, Dinajpur and Debigonj, Panchagarh during 2011-12 to 2012-13 consecutive years in the Old Himalayan Piedmont Plain Soils (AEZ 1). The climatic condition of the experimental area is sub-tropical monsoon as prevailed in the other portion of the country. The lands of the experimental areas were medium lowlands to highlands with medium to good drainage conditions. Potato-Boro- T.aman is a dominant cropping pattern although some other patterns such as Mustard-Maize-T.aman, PotatoMaize-T.aman, Wheat-Jute- T.aman, PotatoGroundnut- T.aman and Boro-Fallow- T.aman were also observed in the study areas.

\section{Collection and analysis of initial soil samples}

Initial soil samples were collected from the different experimental sites. After collecting soil sample, the unwanted materials like gravels, plant roots, leaves etc., were picked up and removed. Then the samples were air dried, well mixed and ground to pass through a 20 mesh sieve and stored in clean plastic bags for physical and chemical analysis. Soil samples were analyzed following standard methods Ali et al. (2013). The soils of the experimental plots were sandy loam in texture and moderately acidic in nature. The organic matter and total nitrogen contents varied from 1.20 to $1.74 \%$ and 0.060 to $0.087 \%$, respectively. Available phosphorus and sulphur contents varied from 16.6 to $25.5 \mathrm{mg} \mathrm{kg}^{-1}$ and 12.0 to $21.9 \mathrm{mg} \mathrm{kg}^{-1}$ respectively. Exchangeable potassium content was $0.09 \mathrm{cmol} \mathrm{kg}^{-1}$ in both of the locations.

\section{Collection and analysis of grain and straw samples}

Grain and straw samples were collected during harvesting period. Grain and straw samples were dried in an oven at about $65^{\circ} \mathrm{C}$ for 48 hours and then ground in a grinding mill to pass through a 20 mesh sieve. The ground grain and straw samples were stored in small paper bags and placed in desiccators for the analysis of different elements. The grain and straw samples were analyzed for the determination of $\mathrm{N}, \mathrm{P}, \mathrm{K}$ and $\mathrm{S}$ contents following the procedures as reported by Ali et al. (2013).

\section{Details of the field experimentation}

The land was well prepared before transplantation. After uniformly leveling, the experimental plots were laid out in randomized complete block design (RCBD) with three replications. The unit plots area was $5 \mathrm{mx} 4 \mathrm{~m}$. Eight treatment combinations of fertilizers were used in the experiments. The treatment combinations were: $\mathrm{T}_{1}(100 \% \mathrm{STB}), \mathrm{T}_{2}\left(\mathrm{~T}_{1}+25 \%\right.$ $\mathrm{N}), \mathrm{T}_{3}\left(\mathrm{~T}_{1}+25 \% \mathrm{NP}\right), \mathrm{T}_{4}\left(\mathrm{~T}_{1}+25 \% \mathrm{NK}\right), \mathrm{T}_{5}\left(\mathrm{~T}_{1}\right.$ $+25 \% \mathrm{PK}), \mathrm{T}_{6}\left(\mathrm{~T}_{1}+25 \% \mathrm{NPK}\right), \mathrm{T}_{7}\left(75 \%\right.$ of $\left.\mathrm{T}_{1}\right)$ and $\mathrm{T}_{8}$ (Control). The sources of $\mathrm{N}, \mathrm{P}, \mathrm{K}, \mathrm{S}$ and Zn were urea, TSP, MoP, gypsum and zinc oxide, respectively. Three healthy seedlings of Binadhan-7 rice of 25-30 days old were transplanted per hill in the plots. Fertilizers were applied to each plot as per treatment. The full dose of all fertilizers except urea was applied as basal to each individual plots during final land preparation. The fertilizers were incorporated into the soils. The first split (1/3) of $\mathrm{N}$ was applied within 10 days after transplanting. The second split (1/3) of $\mathrm{N}$ was applied at maximum vegetative growth stage and incorporated with the soil. The third split (1/3) of $\mathrm{N}$ was applied at or before P.I. stages. Pest control and other intercultural practices like irrigation, etc. were given as and when necessary. Data on yield and yield contributing characters of different crops of the cropping pattern were recorded and statistically analyzed.

\section{Statistical analysis}

The recorded data were compiled and tabulated properly. The recorded data were statistically analyzed to find out the significance of variance resulting from the experimental treatments on various plant characters. Analysis of Variance (ANOVA) was done following RCBD with the help of a computer package program MSTAT and mean differences were adjudged by Duncan's Multiple Range Test (Gomez and Gomez, 1984).

\section{Results and discussion}

\section{Potato}

The tuber yield of potato at three different locations during Rabi season of 2011-12 and 2012-13 are shown in Table 1a to Table 1b. In 2011-12, the highest tuber yield of potato was obtained in treatment $\mathrm{T}_{6}\left(\mathrm{~T}_{1}+25 \% \mathrm{NPK}\right)$ at Debigonj, Panchagarh; which was statistically higher than all other treatments. But at Birgonj, Dinajpur the highest potato yield was recorded in treatment $\mathrm{T}_{4}$ which was statistically identical with treatments $T_{2}, T_{3}$ and $T_{6}$. In 2012-13, the highest tuber yield of potato was also obtained in 
treatment $\mathrm{T}_{6}\left(\mathrm{~T}_{1}+25 \% \mathrm{NPK}\right)$ at Debigonj, Panchagar which was statistically identical with $\mathrm{T}_{4}$ treatments. At Birgonj, Dinajpur the highest potato yield was recorded in treatment $T_{5}$ which was statistically identical with treatment $T_{3}$ and $\mathrm{T}_{6}$. Similar results have also been reported by Ashrafi et al. (2013).

\section{Boro rice}

Application of fertilizers using different combinations significantly affects the grain and straw yield of boro rice at different locations (Table 1a to Table 1b). In 2011-12, the highest grain yield was observed in different treatments at different locations that are in $\mathrm{T}_{3}$ at Debigonj, Panchagarh and $\mathrm{T}_{6}$ at Birgonj, Dinajpur. Straw yield was found highest in $\mathrm{T}_{4}$ at Birgonj, Dinajpur and $\mathrm{T}_{6}$ at Debigonj, Panchagarh. In 2012-13, the highest grain yield was observed in $\mathrm{T}_{6}$ at both of the locations and the treatment $\mathrm{T}_{6}$ is statistically identical with $\mathrm{T}_{3}$ and $\mathrm{T}_{4}$ at Birgonj, Dinajpur. Straw yield was found highest in $\mathrm{T}_{4}$ at Birgonj, Dinajpur and $\mathrm{T}_{6}$ at Debigonj, Panchagarh. In all cases, the lowest yields (grain and straw) were recorded in the control treatment $\left(\mathrm{T}_{8}\right)$. Similar results have been observed in Islam et al. (2006).

\section{ransplanted aman rice}

Results indicate that application of fertilizers at different proportion significantly affected both the grain and straw yields of $\mathrm{T}$. aman rice (Table 1a to Table 1b). In 2012, the highest grain yield was found in treatment $\mathrm{T}_{6}\left(\mathrm{~T}_{1}+25 \% \mathrm{NPK}\right)$. Statistically identical grain yield was observed in treatments $\mathrm{T}_{3}$ at Birgonj, Dinajpur. In case of straw, the highest yield was found in $T_{4}$ at Debigonj, Panchagarh and $\mathrm{T}_{4}$ at Birgonj, Dinajpur. Statistically identical yield was found in $\mathrm{T}_{1}$ and $\mathrm{T}_{3}$ at Birgonj, Dinajpur; and $\mathrm{T}_{6}$ at Debigonj, Panchagar. In 2013, the highest grain yield was found in treatment $\mathrm{T}_{6}\left(\mathrm{~T}_{1}+25 \% \mathrm{NPK}\right)$ at Debigonj, Panchagar and in $\mathrm{T}_{3}\left(\mathrm{~T}_{1}+25 \% \mathrm{NP}\right)$ at Birgonj, Dinajpur. Statistically identical yield was observed in treatments $\mathrm{T}_{2}, \mathrm{~T}_{4}, \mathrm{~T}_{5}$ and $\mathrm{T}_{6}$ at Birgonj, Dinajpur and $T_{2}, T_{3}, T_{4}$ and $T_{5}$ at Debigonj, Panchagarh. In case of straw, the highest yield was found in treatment $\mathrm{T}_{6}\left(\mathrm{~T}_{1}+25 \%\right.$ NPK). Statistically identical yield was found in $\mathrm{T}_{2}, \mathrm{~T}_{3}, \mathrm{~T}_{4}$ and $\mathrm{T}_{5}$ at Birgonj, Dinajpur and $\mathrm{T}_{1}, \mathrm{~T}_{2}$, $\mathrm{T}_{3}, \quad \mathrm{~T}_{4}$ and $\mathrm{T}_{5}$ at Debigonj, Panchagarh. Significantly the lowest yield was obtained in the control plot $\left(\mathrm{T}_{8}\right)$ in all the above cases. Ali et al. (2013) reported almost similar results for T.aman rice cultivation in the same areas.

Table 1a. Effects of fertilizers on the yield $\left(\mathrm{t} \mathrm{ha}^{-1}\right)$ of Potato in Potato-Boro-T. aman pattern during 2011-12 and 2012-13 at Birgonj, Dinajpur

\begin{tabular}{|l|c|c|c|c|c|c|c|c|c|c|}
\hline \multirow{3}{*}{ Treatments } & \multicolumn{4}{|c|}{$2011-12$} & \multicolumn{4}{c|}{$2012-13$} \\
\cline { 2 - 12 } & Potato & \multicolumn{2}{|c|}{ Boro } & \multicolumn{2}{c|}{ T. aman } & Potato & \multicolumn{2}{c|}{ Boro } & \multicolumn{2}{c|}{ T. aman } \\
\cline { 2 - 12 } & Tuber & Grain & Straw & Grain & Straw & Tuber & Grain & Straw & Grain & Straw \\
\hline $\mathrm{T}_{1}=100 \%(\mathrm{STB})$ & $27.71 \mathrm{c}$ & $5.59 \mathrm{de}$ & $6.87 \mathrm{~d}$ & $4.79 \mathrm{~b}$ & $6.13 \mathrm{ab}$ & $24.80 \mathrm{c}$ & $5.30 \mathrm{~cd}$ & $6.40 \mathrm{c}$ & $4.75 \mathrm{~b}$ & $5.65 \mathrm{bc}$ \\
\hline $\mathrm{T}_{2}=\mathrm{T}_{1}+25 \% \mathrm{~N}$ & $29.65 \mathrm{ab}$ & $5.77 \mathrm{~cd}$ & $8.77 \mathrm{ab}$ & $4.75 \mathrm{~b}$ & $5.76 \mathrm{~b}$ & $27.34 \mathrm{~b}$ & $5.90 \mathrm{~b}$ & $6.50 \mathrm{c}$ & $5.10 \mathrm{ab}$ & $6.20 \mathrm{ab}$ \\
\hline $\mathrm{T}_{3}=\mathrm{T}_{1}+25 \% \mathrm{NP}$ & $30.00 \mathrm{ab}$ & $5.95 \mathrm{c}$ & $7.50 \mathrm{~cd}$ & $5.05 \mathrm{ab}$ & $6.02 \mathrm{ab}$ & $27.86 \mathrm{ab}$ & $6.05 \mathrm{ab}$ & $6.80 \mathrm{~b}$ & $5.56 \mathrm{a}$ & $7.06 \mathrm{a}$ \\
\hline $\mathrm{T}_{4}=\mathrm{T}_{1}+25 \% \mathrm{NK}$ & $30.20 \mathrm{a}$ & $5.39 \mathrm{e}$ & $9.15 \mathrm{a}$ & $4.73 \mathrm{~b}$ & $7.08 \mathrm{a}$ & $27.16 \mathrm{~b}$ & $6.03 \mathrm{ab}$ & $7.20 \mathrm{a}$ & $5.15 \mathrm{ab}$ & $6.67 \mathrm{a}$ \\
\hline $\mathrm{T}_{5}=\mathrm{T}_{1}+25 \% \mathrm{PK}$ & $28.68 \mathrm{bc}$ & $6.57 \mathrm{~b}$ & $7.50 \mathrm{~cd}$ & $4.10 \mathrm{c}$ & $4.46 \mathrm{c}$ & $29.58 \mathrm{a}$ & $5.53 \mathrm{c}$ & $5.70 \mathrm{~d}$ & $5.20 \mathrm{ab}$ & $6.73 \mathrm{a}$ \\
\hline $\mathrm{T}_{6}=\mathrm{T}_{1}+25 \% \mathrm{NPK}$ & $29.24 \mathrm{ab}$ & $6.95 \mathrm{a}$ & $7.75 \mathrm{bcd}$ & $5.47 \mathrm{a}$ & $5.83 \mathrm{~b}$ & $28.71 \mathrm{ab}$ & $6.40 \mathrm{a}$ & $7.10 \mathrm{a}$ & $5.50 \mathrm{a}$ & $7.15 \mathrm{a}$ \\
\hline $\mathrm{T}_{7}=75 \%$ of $\mathrm{T}_{1}$ & $24.46 \mathrm{~d}$ & $5.03 \mathrm{f}$ & $8.39 \mathrm{abc}$ & $3.63 \mathrm{c}$ & $3.22 \mathrm{~d}$ & $20.33 \mathrm{~d}$ & $5.13 \mathrm{~d}$ & $5.40 \mathrm{e}$ & $3.65 \mathrm{c}$ & $5.00 \mathrm{c}$ \\
\hline $\mathrm{T}_{8}=$ Control & $14.29 \mathrm{e}$ & $2.65 \mathrm{~g}$ & $3.77 \mathrm{e}$ & $2.23 \mathrm{~d}$ & $2.10 \mathrm{e}$ & $18.28 \mathrm{e}$ & $2.70 \mathrm{e}$ & $3.00 \mathrm{f}$ & $2.51 \mathrm{~d}$ & $3.71 \mathrm{~d}$ \\
\hline CV $(\%)$ & 2.62 & 2.14 & 7.88 & 7.92 & 7.93 & 4.43 & 3.91 & 1.71 & 6.04 & 8.39 \\
\hline
\end{tabular}

STB: Potato (Granula) $=\mathrm{N}_{135} \mathrm{P}_{25} \mathrm{~K}_{135} \mathrm{~S}_{12} \mathrm{Zn}_{2} \mathrm{~B}_{1}$; Boro (BRRIdhan-28) $=\mathrm{N}_{140} \mathrm{P}_{08} \mathrm{~K}_{75} \mathrm{~S}_{10} \mathrm{Zn}_{1} \mathrm{~B}_{0.5}$ and T. aman (Binadhan-7) $=\mathrm{N}_{64} \mathrm{P}_{6} \mathrm{~K}_{32} \mathrm{~S}_{8}$

Table 1b. Effects of fertilizers on the yield $\left(\mathrm{t} \mathrm{ha}^{-1}\right)$ of crops in Potato-Boro-T. aman pattern at Debigonj, Panchagarh

\begin{tabular}{|c|c|c|c|c|c|c|c|c|c|c|}
\hline \multirow[t]{2}{*}{ Treatments } & \multicolumn{5}{|c|}{ 2011-12 } & \multicolumn{5}{|c|}{$2012-13$} \\
\hline & $\begin{array}{l}\text { Potato } \\
\text { Tuber }\end{array}$ & \multicolumn{2}{|c|}{ Boro } & \multicolumn{2}{|c|}{ T. aman } & $\begin{array}{l}\text { Potato } \\
\text { Tuber }\end{array}$ & \multicolumn{2}{|c|}{ Boro } & \multicolumn{2}{|c|}{ T. aman } \\
\hline $\mathrm{T}_{1}=100 \%(\mathrm{STB})$ & $14.70 \mathrm{~d}$ & $5.90 \mathrm{~b}$ & $7.27 b$ & $4.20 \mathrm{~b}$ & $5.16 \mathrm{c}$ & $20.64 c$ & $5.30 \mathrm{~d}$ & $6.03 \mathrm{~cd}$ & $4.10 \mathrm{~b}$ & $4.55 \mathrm{ab}$ \\
\hline $\mathrm{T}_{3}=\mathrm{T}_{1}+25 \% \mathrm{NP}$ & $18.68 \mathrm{c}$ & $7.00 \mathrm{a}$ & $8.77 \mathrm{ab}$ & $4.20 \mathrm{~b}$ & $5.40 \mathrm{bc}$ & $21.31 \mathrm{c}$ & $6.27 b$ & 7.00abc & $4.38 \mathrm{ab}$ & $4.81 \mathrm{ab}$ \\
\hline $\mathrm{T}_{4}=\mathrm{T}_{1}+25 \% \mathrm{NK}$ & $17.76 \mathrm{c}$ & $6.37 \mathrm{ab}$ & $8.55 \mathrm{ab}$ & $4.18 \mathrm{~b}$ & $6.98 \mathrm{a}$ & $24.99 \mathrm{a}$ & $5.73 c$ & $6.50 \mathrm{bcd}$ & $4.20 \mathrm{ab}$ & $4.94 \mathrm{ab}$ \\
\hline $\mathrm{T}_{5}=\mathrm{T}_{1}+25 \% \mathrm{PK}$ & $20.17 b$ & $6.37 \mathrm{ab}$ & $7.50 \mathrm{~b}$ & $4.20 \mathrm{~b}$ & $5.89 \mathrm{bc}$ & $23.83 \mathrm{~b}$ & $5.97 \mathrm{c}$ & $6.95 \mathrm{abc}$ & $4.18 \mathrm{ab}$ & $4.78 \mathrm{ab}$ \\
\hline $\mathrm{T}_{7}=75 \%$ of $\mathrm{T}_{1}$ & $12.45 \mathrm{e}$ & $4.25 \mathrm{c}$ & $4.80 \mathrm{c}$ & $4.15 b$ & $5.06 \mathrm{c}$ & $17.54 d$ & $4.90 \mathrm{e}$ & $5.70 \mathrm{~d}$ & $3.85 \mathrm{~b}$ & $4.58 \mathrm{~b}$ \\
\hline $\mathrm{T}_{8}=$ Control & $09.46 \mathrm{f}$ & $2.00 \mathrm{~d}$ & $3.72 \mathrm{c}$ & $2.47 \mathrm{c}$ & $3.31 \mathrm{~d}$ & $9.49 \mathrm{e}$ & $2.55 \mathrm{f}$ & $3.20 \mathrm{e}$ & $2.28 \mathrm{c}$ & $3.44 \mathrm{c}$ \\
\hline $\mathrm{CV}(\%)$ & 3.27 & 8.14 & 10.06 & 4.70 & 8.44 & 2.83 & 2.59 & 9.76 & 7.89 & 8.25 \\
\hline
\end{tabular}

STB: Potato (Cardinal) $=\mathrm{N}_{150} \mathrm{P}_{18} \mathrm{~K}_{135} \mathrm{~S}_{8} \mathrm{Zn}_{2} \mathrm{~B}_{1}$; Boro (BRRIdhan-28) = $\mathrm{N}_{150} \mathrm{P}_{08} \mathrm{~K}_{75} \mathrm{~S}_{8} \mathrm{Zn}_{1} \mathrm{~B}_{0.5}$ and $\mathrm{T}$. aman $\left(\right.$ Binadhan-7) $=\mathrm{N}_{67} \mathrm{P}_{6} \mathrm{~K}_{32} \mathrm{~S}_{6}$ 
Average yield (t ha $^{-1}$ ) of crops and fertilizer use economy in Potato-Boro- $T$. aman pattern Average yield $\left(\right.$ tha $^{-1}$ ) of crops and results of partial budget analysis of Potato-Boro-T. aman pattern are shown in Table $2 \mathrm{a}$ to Table $2 \mathrm{~b}$. Results of partial budget analysis demonstrated the highest net benefit of $\mathrm{Tkha}^{-1} 4,42,632$ in $\mathrm{T}_{6}$ followed by Tkha ${ }^{-1} 4,31,752$ and $\mathrm{Tkha}^{-1} 4,24,717$ in $\mathrm{T}_{3}$ and $\mathrm{T}_{5}$ treatments at Birgonj, Dinajpur (Table 2a). The highest net benefit of $\mathrm{Tkha}^{-1}$ $3,79,267$ was obtained in $\mathrm{T}_{6}$ followed by $\mathrm{Tkha}^{-1}$ 3,48,382 and Tkha $^{-1} 3,38,367$ in $\mathrm{T}_{5}$ and $\mathrm{T}_{4}$ treatments at Debigonj, Panchagarh (Table 2b). The highest MBCR of 4.57 and 4.75 was obtained in $T_{3}$ at Birgonj, Dinajpur and $T_{6}$ treatment at Debigonj. Based on the most profitable treatment, the following doses of fertilizers are recommended for Potato-BoroT.aman cropping pattern: $\mathrm{N}_{169} \mathrm{P}_{31} \mathrm{~K}_{135} \mathrm{~S}_{12} \mathrm{Zn}_{2} \mathrm{~B}_{1}$ $\mathrm{N}_{175} \mathrm{P}_{10} \mathrm{~K}_{75} \mathrm{~S}_{10} \mathrm{Zn}_{1} \mathrm{~B}_{0.5}-\mathrm{N}_{80} \mathrm{P}_{7.5} \mathrm{~K}_{32} \mathrm{~S}_{8}$ at Birgonj, Dinajpur and $\mathrm{N}_{188} \mathrm{P}_{23} \mathrm{~K}_{169} \mathrm{~S}_{8} \mathrm{Zn}_{2} \mathrm{~B}_{1}$ $\mathrm{N}_{188} \mathrm{P}_{10} \mathrm{~K}_{94} \mathrm{~S}_{8} \mathrm{Zn}_{1} \mathrm{~B}_{0.5}-\mathrm{N}_{84} \mathrm{P}_{7.5} \mathrm{~K}_{40} \mathrm{~S}_{6}$ at Debigonj, Panchagarh. Islam et al. (2006) reported almost similar trend of results for development of fertilizer recommendation for Potato-BoroT.aman cropping pattern in the Tista Meander Floodplain Soils (AEZ 3) and Old Brahmaputra Floodplain Soils (AEZ 9).

Table 2a. Effects of fertilizers on the average yield ( $\left.\mathrm{t} \mathrm{ha}^{-1}\right)$ of crops and fertilizer use economy in PotatoBoro-T. aman pattern at Birgonj, Dinajpur

\begin{tabular}{|c|c|c|c|c|c|c|c|c|c|c|}
\hline \multirow[t]{3}{*}{ Treatments } & \multicolumn{5}{|c|}{ Average (2011-12 \& 2012-13) } & Gross & Fert. cost & Net return & Marginal return & \multirow[t]{3}{*}{ MBCR } \\
\hline & \multirow{2}{*}{$\begin{array}{l}\text { Potato } \\
\text { Tuber }\end{array}$} & \multicolumn{2}{|c|}{ Boro } & \multicolumn{2}{|c|}{ T. aman } & \multirow{2}{*}{\multicolumn{4}{|c|}{ Tk. ha ${ }^{-1}$}} & \\
\hline & & Grain & Straw & Grain & Straw & & & & & \\
\hline $\mathrm{T}_{1}=100 \%(\mathrm{STB})$ & 26.26 & 5.44 & 6.09 & 4.77 & 5.89 & $4,27,730$ & 35,563 & $3,92,167$ & 147217 & 4.14 \\
\hline $\mathrm{T}_{2}=\mathrm{T}_{1}+25 \% \mathrm{~N}$ & 28.5 & 5.84 & 7.63 & 4.93 & 5.98 & $4,62,160$ & 39,388 & $4,22,772$ & 177822 & 4.51 \\
\hline $\mathrm{T}_{3}=\mathrm{T}_{1}+25 \% \mathrm{NP}$ & 28.93 & 6.00 & 7.15 & 5.31 & 6.54 & $4,72,640$ & 40,888 & $4,31,752$ & 186802 & 4.57 \\
\hline $\mathrm{T}_{4}=\mathrm{T}_{1}+25 \% \mathrm{NK}$ & 28.68 & 5.71 & 8.18 & 4.94 & 6.88 & $4,61,610$ & 42,438 & $4,19,172$ & 174,222 & 4.11 \\
\hline $\mathrm{T}_{5}=\mathrm{T}_{1}+25 \% \mathrm{PK}$ & 29.13 & 6.05 & 7.43 & 4.65 & 5.60 & $4,64,830$ & 40,113 & $4,24,717$ & 179767 & 4.48 \\
\hline $\mathrm{T}_{6}=\mathrm{T}_{1}+25 \% \mathrm{NPK}$ & 28.96 & 6.68 & 7.43 & 5.49 & 6.49 & $4,86,070$ & 43,438 & $4,42,632$ & 197,682 & 4.55 \\
\hline $\mathrm{T}_{7}=5 \%$ of $\mathrm{T}_{1}$ & 22.39 & 5.08 & 6.89 & 3.64 & 4.11 & $3,65,700$ & 27,238 & $3,38,462$ & 93512 & 3.43 \\
\hline $\mathrm{T}_{8}=$ Control & 16.29 & 2.68 & 3.39 & 2.37 & 2.91 & $2,44,950$ & - & $2,44,950$ & - & \\
\hline
\end{tabular}

Grain $=15$ Tk. $\mathrm{kg}^{-1} ;$ Straw $=1$ Tk. $\mathrm{kg}^{-1} ;$ Potato $=10$ Tk. $\mathrm{kg}^{-1} ; \mathrm{N}=45$ Tk. kg ${ }^{-1} ; \mathrm{P}=150$ Tk. kg ${ }^{-1} ; \mathrm{K}=50$ Tk. $\mathrm{kg}^{-1} ; \mathrm{S}=55 \mathrm{Tk}^{\mathrm{kg}} \mathrm{kg}^{-1}$ and Zn $=$ $102 \mathrm{Tk} . \mathrm{kg}^{-1}, \mathrm{MBCR}=$ Marginal benefit cost ratio.

Table 2b. Effects of fertilizers on the average yield $\left(\mathrm{t} \mathrm{ha}^{-1}\right)$ of crops and fertilizer use economy in PotatoBoro-T. aman pattern at Debigonj, Panchagarh

\begin{tabular}{|c|c|c|c|c|c|c|c|c|c|c|}
\hline \multirow[t]{3}{*}{ Treatments } & \multicolumn{5}{|c|}{ Average (2011-12 \& 2012-13) } & Gross & Fert. cost & Net return & Marginal & \multirow[t]{3}{*}{ MBCR } \\
\hline & \multirow{2}{*}{$\begin{array}{l}\text { Potato } \\
\text { Tuber }\end{array}$} & \multicolumn{2}{|c|}{ Boro } & \multicolumn{2}{|c|}{ T. aman } & \multirow{2}{*}{\multicolumn{4}{|c|}{ Tk. ha ${ }^{-1}$}} & \\
\hline & & Grain & Straw & Grain & Straw & & & & & \\
\hline $\mathrm{T}_{1}=100 \%(\mathrm{STB})$ & 17.67 & 5.6 & 6.65 & 4.15 & 4.86 & $3,34,455$ & 35,335 & $2,99,120$ & $1,27,660$ & 3.61 \\
\hline $\mathrm{T}_{2}=\mathrm{T}_{1}+25 \% \mathrm{~N}$ & 19.80 & 6.09 & 7.71 & 4.21 & 5.09 & $3,65,305$ & 39,473 & $3,25,970$ & $1,54,510$ & 3.91 \\
\hline $\mathrm{T}_{3}=\mathrm{T}_{1}+25 \% \mathrm{NP}$ & 19.99 & 6.64 & 7.89 & 4.29 & 5.11 & $3,76,845$ & 40,673 & $3,36,172$ & $1,64,712$ & 4.05 \\
\hline $\mathrm{T}_{4}=\mathrm{T}_{1}+25 \% \mathrm{NK}$ & 21.38 & 6.05 & 7.53 & 4.19 & 5.96 & $3,80,890$ & 42,523 & $3,38,367$ & $1,66,907$ & 3.93 \\
\hline $\mathrm{T}_{5}=\mathrm{T}_{1}+25 \% \mathrm{PK}$ & 22.00 & 6.17 & 7.23 & 4.19 & 5.34 & $3,87,965$ & 39,583 & $3,48,382$ & $1,76,922$ & 4.47 \\
\hline $\mathrm{T}_{6}=\mathrm{T}_{1}+25 \% \mathrm{NPK}$ & 23.78 & 6.74 & 8.39 & 4.67 & 5.73 & $4,22,990$ & 43,723 & $3,79,267$ & $2,07,807$ & 4.75 \\
\hline $\mathrm{T}_{7}=75 \%$ of $\mathrm{T}_{1}$ & 14.99 & 4.58 & 5.25 & 4.00 & 4.83 & $2,88,678$ & 26,993 & $2,61,685$ & 90,225 & 3.34 \\
\hline $\mathrm{T}_{8}=$ Control & 9.48 & 2.28 & 3.46 & 2.38 & 3.38 & $1,71,460$ & - & $1,71,460$ & - & - \\
\hline
\end{tabular}

Grain $=15$ Tk. $\mathrm{kg}^{-1} ;$ Straw $=1$ Tk. $\mathrm{kg}^{-1} ;$ Potato $=10$ Tk. $\mathrm{kg}^{-1} ; \mathrm{N}=45$ Tk. kg ${ }^{-1} ; \mathrm{P}=150$ Tk. kg ${ }^{-1} ; \mathrm{K}=50$ Tk. $\mathrm{kg}^{-1} ; \mathrm{S}=55 \mathrm{Tk}^{\mathrm{kg}} \mathrm{kg}^{-1}$ and Zn $=$ $102 \mathrm{Tk} . \mathrm{kg}^{-1}, \mathrm{MBCR}=$ Marginal benefit cost ratio.

\section{Nutrient balance in soil}

Nutrient uptake by Potato-Boro-T. aman cropping pattern at different locations was influenced due to different treatments (Table 3a and Table $3 b$ ). The highest $\mathrm{N}, \mathrm{P}$ and $\mathrm{K}$ uptake was observed in treatment $\mathrm{T}_{6}$ at Birgonj, Dinajpur. Treatment $\mathrm{T}_{6}$ also produced the highest $\mathrm{N}, \mathrm{K}$ and $\mathrm{S}$ uptake at Debigonj, Panchagarh. The highest $\mathrm{S}$ uptake in treatment $\mathrm{T}_{5}$ at Birgonj, Dinajpur and $\mathrm{P}$ uptake in $\mathrm{T}_{3}$ at Debigonj, Panchagarh was recorded. From Table $3 \mathrm{a}$ and Table $3 b$, there observed negative balance of nutrients $(\mathrm{N}, \mathrm{P}, \mathrm{K}$ and $\mathrm{S})$ in both the locations after two years cropping in the Old Himalayan Piedmont Plain Soils (AEZ 1) of this study. The negative balance of nutrients were $202-346 \mathrm{~kg}$ $\mathrm{N}, 17-32 \mathrm{~kg} \mathrm{P}, 204-349 \mathrm{~kg} \mathrm{~K}$ and $2-21 \mathrm{~kg} \mathrm{~S}$ per hectare at Birgonj, Dinajpur but were 146 $275 \mathrm{~kg} \mathrm{~N}, 17-24 \mathrm{~kg} \mathrm{P}, 118-171 \mathrm{~kg} \mathrm{~K}$ and $7-$ $24 \mathrm{~kg} \mathrm{~S}$ per hectare at Debigonj, Panchagarh. Similar trends of nutrient balance for PotatoBoro-T. aman cropping pattern in the Tista Meander Floodplain Soils (AEZ 3) and Old Brahmaputra Floodplain Soils (AEZ 9) were also reported by Islam et al. (2006). 
Table 3a. Fertilization effects on nutrient balance $\left(\mathrm{kg} \mathrm{ha}^{-1}\right)$ due to Potato-Boro-T. aman cropping in soil at Birgonj, Dinajpur

\begin{tabular}{|c|c|c|c|c|c|c|c|c|c|c|c|}
\hline \multicolumn{4}{|c|}{ Nutrient added } & \multicolumn{4}{c|}{ Nutrient uptake } & \multicolumn{4}{c|}{ Nutrient balance } \\
\hline $\mathrm{N}^{*}$ & $\mathrm{P}$ & $\mathrm{K}$ & $\mathrm{S}$ & $\mathrm{N}$ & $\mathrm{P}$ & $\mathrm{K}$ & $\mathrm{S}$ & $\mathrm{N}$ & $\mathrm{P}$ & $\mathrm{K}$ & $\mathrm{S}$ \\
\hline 339 & 39 & 242 & 30 & 426 & 61 & 474 & 39 & -290 & -22 & -232 & -9 \\
\hline 424 & 39 & 242 & 30 & 439 & 67 & 591 & 44 & -269 & -28 & -349 & -14 \\
\hline 424 & 49 & 242 & 30 & 436 & 78 & 517 & 49 & -266 & -29 & -275 & -19 \\
\hline 424 & 39 & 303 & 30 & 492 & 71 & 521 & 50 & -322 & -32 & -218 & -20 \\
\hline 339 & 49 & 303 & 30 & 482 & 78 & 533 & 51 & -346 & -29 & -230 & -21 \\
\hline 424 & 49 & 303 & 30 & 505 & 80 & 616 & 46 & -335 & -31 & -313 & -16 \\
\hline 254 & 29 & 182 & 30 & 304 & 46 & 386 & 32 & -202 & -17 & -204 & -2 \\
\hline
\end{tabular}

* Assume 40\% nitrogen use efficiency

Table 3b. Fertilization effects on nutrient balance $\left(\mathrm{kg} \mathrm{ha}^{-1}\right)$ due to Potato-Boro-T. aman cropping in soil at Debigonj, Panchagarh

\begin{tabular}{|c|c|c|c|c|c|c|c|c|c|c|c|}
\hline \multicolumn{4}{|c|}{ Nutrient added } & \multicolumn{4}{|c|}{ Nutrient uptake } & \multicolumn{4}{c|}{ Nutrient balance } \\
\hline $\mathrm{N}^{*}$ & $\mathrm{P}$ & $\mathrm{K}$ & $\mathrm{S}$ & $\mathrm{N}$ & $\mathrm{P}$ & $\mathrm{K}$ & $\mathrm{S}$ & $\mathrm{N}$ & $\mathrm{P}$ & $\mathrm{K}$ & $\mathrm{S}$ \\
\hline 367 & 32 & 242 & 22 & 363 & 49 & 399 & 34 & -216 & -17 & -157 & -12 \\
\hline 459 & 32 & 242 & 22 & 405 & 53 & 413 & 34 & -221 & -21 & -171 & -12 \\
\hline 459 & 40 & 242 & 22 & 414 & 64 & 400 & 41 & -230 & -24 & -158 & -19 \\
\hline 459 & 32 & 303 & 22 & 378 & 56 & 452 & 40 & -194 & -24 & -149 & -18 \\
\hline 367 & 40 & 303 & 22 & 383 & 58 & 421 & 37 & -236 & -18 & -118 & -15 \\
\hline 459 & 40 & 303 & 22 & 459 & 63 & 474 & 46 & -275 & -23 & -171 & -24 \\
\hline 275 & 24 & 181 & 22 & 319 & 42 & 343 & 29 & -209 & -18 & -162 & -7 \\
\hline 0 & 0 & 0 & 0 & 146 & 21 & 193 & 13 & -146 & -21 & -193 & -13 \\
\hline
\end{tabular}

Assume 40\% nitrogen use efficiency

\section{Conclusion}

The highest yield, nutrient uptake and net benefit found in treatment $\mathrm{T}_{6}\left(\mathrm{~T}_{1}+25 \% \mathrm{NPK}\right)$ both at Birgonj, Dinajpur and Debigonj, Panchagarh. From $\mathrm{T}_{6}$ treatment, doses of fertilizer nutrients $\mathrm{N}_{169} \mathrm{P}_{31} \mathrm{~K}_{135} \mathrm{~S}_{12} \mathrm{Zn}_{2} \mathrm{~B}_{1} \quad-\mathrm{N}_{175} \mathrm{P}_{10} \mathrm{~K}_{75} \mathrm{~S}_{10} \mathrm{Zn}_{1} \mathrm{~B}_{0.5} \quad-$ $\mathrm{N}_{80} \mathrm{P}_{7.5} \mathrm{~K}_{32} \mathrm{~S}_{8}$ at Birgonj, Dinajpur and $\mathrm{N}_{188} \mathrm{P}_{23} \mathrm{~K}_{169} \mathrm{~S}_{8} \mathrm{Zn}_{2} \mathrm{~B}_{1} \quad-\quad \mathrm{N}_{188} \mathrm{P}_{10} \mathrm{~K}_{94} \mathrm{~S}_{8} \mathrm{Zn}_{1} \mathrm{~B}_{0.5} \quad$ $\mathrm{N}_{84} \mathrm{P}_{7.5} \mathrm{~K}_{40} \mathrm{~S}_{6}$ in $\mathrm{kg} \mathrm{ha}{ }^{-1}$ at Debigonj, Panchagarh were recommended for Potato-Boro-T.aman cropping pattern in the Old Himalayan Piedmont Plain Soils under AEZ 1 of North-West Bangladesh.

\section{Acknowledgement}

The authors gratefully acknowledged the financial support for this study under a Coordinated Project on Soil Fertility and Fertilizer Management for Crops and Cropping Patterns: BINA component of Sponsored Public Goods Research (SPGR), PIU-BARC, NATP: phase-1.

\section{References}

Ali, M.M.; Rahman, M.H.; Rahman, M.H. and Khan, M.K. 2013. Effect of Fertilizers on the yield and nutrient uptake by transplanted Aman rice (Binadhan-7) grown in two soils of north-west Bangladesh. J. Environ. \& Natural Res., 6 (2): 115-120.
Ashrafi, R.; Ali, M.M.; Rahman, M.H.;. Khan, M.R. and Khan, M.K. 2013. Fertilization to Potato Grown in old Himalayan Piedmont Plain Soils. J. Bangladesh Soc. Agric. Sci. Technol., 10 (1 \& 2): 125129.

Ali, M.M.; Saheed, S.M.; Kubota, D.; Masunaga, T. and Wakatsuki, T. 1997a. Soil degradation during the period 1967-1995 in Bangladesh. I. Carbon and Nitrogen. Soil Sci. Plant Nutri., 43 (4): 863-878.

Ali, M.M.; Saheed, S.M.; Kubota, D.; Masunaga, T. and Wakatsuki, T. 1997b. Soil degradation during the period 1967-1995 in Bangladesh. II. Selected chemical characters. Soil Sci. Plant Nutri., 43(4): 879-890.

Abedin M. Z. and Mukhopadhya, D. 1990. Cropping systems based fertilizer recommendations and soil fertility investigation in farmers fields. TCP/BGD/8835/Field Document No. 1. FAO, Dhaka.

Bhuiyan, N. I.1993. Banlanced fertilization in maximizing yield with rice based cropping system. A paper Presented in two day training workshop on "Yield maximizing with balanced fertilization with emphasis on potash" held at BINA, Mymensingh. April 28-29.

FRG. 2012. Fertilizer Recommendation Guide, 
Bangladesh Agricultural Research Council (BARC), Farmgate, Dhaka 1215. P 191.

Fageria N. K.; Baligar, V. C. and Jounes, C. A. 1991. Growth and Mineral Nutrition of Field Crops. Marcel Dekker, Inc. New York, Besel. Hong Kong, pp 77-124.

Gomez, K. A. and Gomez, A. A. 1984. Statistical procedures for agricultural research (second edition). An International Rice Research Institute Book. John Wiley \& Sons, Inc., USA.

Islam, M. F.; Jahiruddin, M. and Razia, M. S. 2006. On-farm research and development on integrated soil fertility and fertilizer management. Project completion report -SFFP II (1999-2000 to 2005-2006). On-farm Research Division, BARI, Gazipur. p. 45-47.
Karim, Z. 1995. Mixed fertilizer, Keynote speech delivered at the seminar on "Mixed fertilizers prospect and use in Bangladesh" Organized by the institute of chemists and chemical technologist (ICCT).BCIC, Dhaka, Nov. 25, 1995.

Miah, M.M.U. 1994. Prospects and problem of organic farming in Bangladesh. A paper presented in a three day workshop on "Integrated nutrient management for sustainable Agriculture" held at SRDI, Dhaka, June 26-28, 1994.

Saheed, S.M. 1991. Land degradation and land stability constraints to crop production. In Paper for the National Workshop on Risk Management in Bangladesh Agriculture, BARC, Dhaka 